\title{
Citrus pulp in lamb diets: intake, digestibility, and ruminal parameters
}

\section{Polpa cítrica em dietas para cordeiros: consumo, digestibilidade e parâmetros ruminais}

\author{
Eduardo Lucas Terra Peixoto ${ }^{1 *}$; Mirton José Frota Morenz ${ }^{2}$; \\ Carlos Elysio Moreira da Fonseca ${ }^{3}$; Elizabeth dos Santos Moura ${ }^{4}$; \\ Karla Rodrigues de Lima ${ }^{5}$; Fernando Cesar Ferraz Lopes²; \\ Luciano da Silva Cabral ${ }^{6}$
}

\begin{abstract}
This study aimed to evaluate the viability of replacing corn meal with citrus pulp $(0,25,50,75$, and 100 $\%$ dry matter of corn meal) by evaluating several nutritional parameters such as intake and digestibility of nutrients, and ruminal fermentation parameters. The diets were formulated to be isoproteic with a roughage:concentrate ratio of 60:40. Five crossbred lambs with an initial average weight of $26.1 \pm 1.8$ $\mathrm{kg}$ were used and distributed in a 5 x 5 Latin Square design. For digestibility of nutrients was carried out to feed, orts, and feces collection. The evaluated nutrients were dry matter, crude protein, ether extract, ash, neutral detergent fiber, fiber acid detergent and lignin. Were determined nitrogen and carbohydrate fractions, and ruminal fermentation parameters $(\mathrm{N}-\mathrm{NH} 3$ and ruminal $\mathrm{pH})$. The results were subjected to analysis of variance and regression analysis (t-test; $\alpha=0.05$ ). Citrus pulp inclusion in the diets did not affect intake and digestibility of nutrients, or the $\mathrm{pH}$ and the $\mathrm{NH}_{3}-\mathrm{N}$ content of the rumen fluid. Citrus pulp can be used as a total substitute for corn in concentrate or up to $26.5 \%$ in the total ration for lambs (dry basis).
\end{abstract}

Key words: By-product, $\mathrm{NH}_{3}$, nutrients, $\mathrm{pH}$, sheep

\section{Resumo}

Objetivou-se avaliar a viabilidade da substituição do milho por polpa cítrica peletizada $(0 ; 25 ; 50 ; 75$ e $100 \%$ da MS de milho) em dietas para cordeiros, com base em variáveis nutricionais. Foram avaliadas as variáveis: consumo e digestibilidade dos nutrientes, e os parâmetros de fermentação ruminal. As dietas foram formuladas para serem isoproteicas, com relação volumoso:concentrado de 60:40. Foram

\footnotetext{
${ }^{1}$ Prof. Dr., Instituto de Estudos em Desenvolvimento Agrário e Regional, Universidade Federal do Sul e Sudeste do Pará, UNIFESSPA, Marabá, PA, Brasil. E-mail: eltpeixoto@unifesspa.edu.br

2 Pesquisadores EMBRAPA Gado de Leite, Juiz de Fora, MG, Brasil. E-mail: mirton.morenz@embrapa.br; fernando.lopes@ embrapa.br

${ }^{3}$ Prof. Dr., Dept ${ }^{\circ}$ de Produção Animal, Universidade Federal Rural do Rio de Janeiro, UFRRJ, Seropédica, RJ, Brasil. E-mail: carloselysio@hotmail.com

${ }^{4}$ Discente de Doutorado em Ciência Animal, Universidade Estadual de Londrina, UEL, Londrina, PR, Brasil. E-mail: elizazootec@ hotmail.com

5 Discente de Doutorado em Ciência Animal, Universidade Estadual do Norte Fluminense, UENF, Campos dos Goytacazes, RJ, Brasil. E-mail: karla.rural@yahoo.com.br

${ }^{6}$ Prof. Dr., Dept ${ }^{\circ}$ de Zootecnia e Extensão Rural, Universidade Federal do Mato Grosso, UFMT, Cuiabá, MT, Brasil. E-mail: cabralls@ufmt.br

* Author for correspondence
} 
utilizados cinco borregos mestiços com peso inicial médio de $26,1 \pm 1,8 \mathrm{~kg}$ distribuídos segundo um delineamento em quadrado latino 5 x 5. Para a determinação da digestibilidade dos nutrientes foi realizada a coleta de amostras de alimentos oferecidos e sobras e coleta total de fezes. Os nutrientes avaliados foram matéria seca, proteína bruta, extrato etéreo, cinzas, fibra em detergente neutro, fibra em detergente ácido e lignina. Foram determinadas as frações nitrogenadas e de carboidratos, e os parâmetros de fermentação ruminal (N-NH3 e pH ruminal). Os resultados foram interpretados de acordo com a análise de variância, e as médias estudadas por meio de análise de regressão (teste " $t$ "; $\alpha=0,05$ ). Não houve efeito da inclusão de polpa cítrica à dieta sobre o consumo, coeficientes de digestibilidade dos nutrientes, bem como no $\mathrm{pH}$ e concentrações de $\mathrm{N}^{-\mathrm{NH}_{3}}$ no líquido ruminal. O consumo de nutrientes foi capaz de atender as exigências nutricionais preconizadas para a referida categoria. A polpa cítrica pode ser utilizada como substituta total do milho na mistura concentrada ou em até $26,5 \%$ da ração total (base seca) para cordeiros.

Palavras-chave: Coproduto, ${\mathrm{N}-\mathrm{NH}_{3}}_{3}$, nutrientes, ovinos, $\mathrm{pH}$

\section{Introduction}

Approximately $60 \%$ of the cost in lamb production is attributed to animal feed. Food energy and protein concentrates are subjected to price fluctuations throughout the year, and the price of the main ingredients used in the formulation of concentrates (corn and soybean meal) increases routinely. Thus, the use of agro-industrial byproducts might be an alternative to replace food energy and protein concentrates, increasing the efficiency and reducing the economic costs of the production system and, consequently, making it more competitive.

In this context, citrus pulp has nutritional characteristics that make it a potential substitute for corn in ruminant diets, owing to its high levels of non-fibrous carbohydrates and its fiber fraction with high digestibility (MIRON et al., 2001). As the largest worldwide producer of this citrus juice industry by-product, Brazil has a high capacity for citrus pulp utilization in animal feed, which might result in the improvement of nutritional, productive, and economic parameters of many livestock production systems (ASSIS et al., 2004; BUENO et al., 2002; FEGEROS et al., 1995; FRANZOLIN et al., 2000; HENRIQUE et al., 2003, 2004; RODRIGUES et al., 2008a, 2008b).
Citrus pulp is an energy-rich concentrate feed, characterized by low starch and high pectin content (NOCEK; TAMMINGA, 1991). According to Van Soest (1994), pectins are compounds composed of galacturonic acid, which provides high availability in the rumen ecosystem and adequate ruminal fiber degradation due its high cation exchange capacity. Another major advantage is that pectin fermentation stimulates the production of acetic acid instead of lactic acid, avoiding the decrease in ruminal $\mathrm{pH}$ (WING et al., 1988). Thus, its use may be strategic to replace corn in diets with high concentrate in order to reduce the risk of rumen acidosis.

Although several studies have considered the use of citrus pulp in ruminant diets, the total replacement of corn by citrus pulp in diets with high concentrate level has rarely been described. Furthermore, most investigations have provided specific performance data, and digestibility and ruminal parameters, but have not adequately integrated this information (HENRIQUE; SAMPAIO, 1998; LEIVA et al., 2000; HENRIQUE et al., 2003, 2004).

Therefore, this study aimed to evaluate the viability of replacing corn with citrus pulp pellets in lamb diets, by considering several nutritional variables. 


\section{Material and Methods}

The experiment was carried out at the Institute of Animal Sciences, Universidade Federal Rural do Rio de Janeiro, Brazil, from September to November 2009. The overall aim was to evaluate citrus pulp inclusion, which replaced ground corn in the concentrate.

Citrus pulp was included in the energy-rich mixture of the concentrate in order to obtain a citrus pulp/corn concentration of $0,25,50,75$, and $100 \mathrm{~g} \mathrm{~kg}^{-1}$ [dry matter (DM) basis]. Five crossbred male lambs with an average body weight of 26.1 $\pm 1.8 \mathrm{~kg}$ distributed in a $5 \times 5$ Latin Square design were used. Each experimental period lasted $14 \mathrm{~d}$, $7 \mathrm{~d}$ for adaptation to the experimental diets and 7 $\mathrm{d}$ for sampling, totaling $70 \mathrm{~d}$ for total length of the experiment. Animals were managed twice daily (07:00 $\mathrm{h}$ and 17:00 h), when they were fed and their cages were cleaned.
Experimental diets consisted of concentrate and coast cross grass hay (Cynodon spp.) plus $30 \mathrm{~g}$ of mineral mixture with a $60: 40$ roughage:concentrate ratio. The chemical composition of the mineral mixture was: phosphate, $20 \mathrm{~g} \mathrm{~kg}^{-1}$; calcium, $53 \mathrm{~g} \mathrm{~kg}^{-}$ 1; sodium, $45 \mathrm{~g} \mathrm{~kg}^{-1}$; sulfur, $6 \mathrm{~g} \mathrm{~kg}^{-1}$; magnesium, $2 \mathrm{~g}$ $\mathrm{kg}^{-1}$; cobalt, $0.06 \mathrm{~g} \mathrm{~kg}^{-1}$; copper, $0.012 \mathrm{~g} \mathrm{~kg}^{-1}$; iodine, $0.045 \mathrm{~g} \mathrm{~kg}^{-1}$; manganese, $0.47 \mathrm{~g} \mathrm{~kg}^{-1}$; selenium, $0.007 \mathrm{~g} \mathrm{~kg}^{-1}$; zinc, $2.1 \mathrm{~g} \mathrm{~kg}^{-1}$; iron, $0.35 \mathrm{~g} \mathrm{~kg}^{-1}$; and fluorine, $0.2 \mathrm{~g} \mathrm{~kg}^{-1}$. Animals had ad libitum access to water.

The concentrate rations were formulated with ground corn, and/or citrus pulp and soybean meal (Table 1), so that they were isoproteic and met the nutritional requirements of lambs, according to their category and body weight plus $10 \%$ of the requirements recommended by NRC (2007) to allow orts (Table 2). At the beginning and end of each evaluation period, animals were weighed to adjust their diets.

Table1. Chemical composition of feeds used in experimental diets (DM basis).

\begin{tabular}{lcccc}
\hline \multicolumn{1}{c}{ Feed } & Hay & Corn meal & Citrus pulp & Soybean meal \\
\hline Dry matter $\left(\mathrm{g} \mathrm{kg}^{-1}\right)$ & 859.0 & 868.0 & 860.0 & 873.0 \\
Organic matter $\left(\mathrm{g} \mathrm{kg}^{-1}\right)$ & 933.0 & 964.0 & 942.0 & 929.0 \\
Crude protein $\left(\mathrm{g} \mathrm{kg}^{-1}\right)$ & 103.0 & 130.0 & 60.0 & 538.0 \\
Ether extract $\left(\mathrm{g} \mathrm{kg}^{-1}\right)$ & 8.0 & 6.0 & 24.0 & 9.0 \\
$\mathrm{NDF}^{1}\left(\mathrm{~g} \mathrm{~kg}^{-1}\right)$ & 802.0 & 103.0 & 183.0 & 184.0 \\
$\mathrm{ADF}^{2}\left(\mathrm{~g} \mathrm{~kg}^{-1}\right)$ & 365.0 & 64.0 & 137.0 & 88.0 \\
$\left.\mathrm{Cellulose}_{\mathrm{g} \mathrm{kg}}^{-1}\right)$ & 260.0 & 55.0 & 93.0 & 62.0 \\
$\operatorname{Lignin}_{\left(\mathrm{g} \mathrm{kg}^{-1}\right)}$ & 75.0 & 10.0 & 28.0 & 23.0 \\
$\mathrm{TC}^{3}\left(\mathrm{~g} \mathrm{~kg}^{-1}\right)$ & 822.0 & 829.0 & 858.0 & 382.0 \\
$\mathrm{NFC}^{4}\left(\mathrm{~g} \mathrm{~kg}^{-1}\right)$ & 73.0 & 747.0 & 695.0 & 231.0 \\
$\mathrm{TDN}^{5}\left(\mathrm{~g} \mathrm{~kg}^{-1}\right)$ & 608.0 & 838.0 & 806.0 & 791.0 \\
\hline
\end{tabular}

${ }^{1}$ Neutral detergente fiber; ${ }^{2}$ Acid detergente fiber; ${ }^{3}$ Total carbohydrate, Sniffen et al. (1992); ${ }^{4}$ Non-fibrous carbohydrate, Sniffen et al. (1992); ${ }^{5}$ Total nutrients digestible, Weiss et al. (1998). 
Table 2. Feed and chemical composition of experimental diets.

\begin{tabular}{|c|c|c|c|c|c|}
\hline \multirow{2}{*}{ Feed } & \multicolumn{5}{|c|}{ Replacement level (\% DM basis) } \\
\hline & 0 & 25 & 50 & 75 & 100 \\
\hline Hay $\left(\mathrm{g} \mathrm{kg}^{-1}\right.$ as fed $)$ & 600.0 & 600.0 & 600.0 & 600.0 & 600.0 \\
\hline Corn meal ( $\mathrm{g} \mathrm{kg}^{-1}$ as fed $)$ & 310.0 & 239.0 & 143.0 & 55.0 & 0.0 \\
\hline Citrus pulp ( $\mathrm{g} \mathrm{kg}^{-1}$ as fed $)$ & 0.0 & 60.0 & 143.0 & 218.0 & 265.0 \\
\hline Soybean meal ( $\mathrm{g} \mathrm{kg}^{-1}$ as fed) & 90.0 & 101.0 & 115.0 & 128.0 & 135.0 \\
\hline \multicolumn{6}{|l|}{ Chemical composition } \\
\hline Dry matter $\left(\mathrm{g} \mathrm{kg}^{-1}\right)$ & 863.0 & 863.0 & 862.0 & 861.0 & 861.0 \\
\hline Organic matter $\left(\mathrm{g} \mathrm{kg}^{-1}\right.$ of DM) & 942.0 & 941.0 & 938.0 & 936.0 & 935.0 \\
\hline Crude protein $\left(\mathrm{g} \mathrm{kg}^{-1}\right.$ of $\left.\mathrm{DM}\right)$ & 150.5 & 150.8 & 150.8 & 150.9 & 150.3 \\
\hline Ether extract $\left(\mathrm{g} \mathrm{kg}^{-1}\right.$ of $\left.\mathrm{DM}\right)$ & 7.0 & 9.0 & 10.0 & 12.0 & 12.0 \\
\hline $\mathrm{NDF}^{1}\left(\mathrm{~g} \mathrm{~kg}^{-1}\right.$ of DM$)$ & 530.0 & 535.0 & 543.0 & 550.0 & 554.0 \\
\hline $\mathrm{ADF}^{2}\left(\mathrm{~g} \mathrm{~kg}^{-1}\right.$ of $\left.\mathrm{DM}\right)$ & 247.0 & 251.0 & 258.0 & 264.0 & 267.0 \\
\hline $\operatorname{Lignin}\left(\mathrm{g} \mathrm{kg}^{-1}\right.$ of $\left.\mathrm{DM}\right)$ & 50.0 & 51.0 & 53.0 & 55.0 & 55.0 \\
\hline $\mathrm{TC}^{3}\left(\mathrm{~g} \mathrm{~kg}^{-1}\right.$ of $\left.\mathrm{DM}\right)$ & 784.0 & 781.0 & 777.0 & 774.0 & 772.0 \\
\hline $\mathrm{NFC}^{4}\left(\mathrm{~g} \mathrm{~kg}^{-1}\right.$ of $\left.\mathrm{DM}\right)$ & 296.0 & 287.0 & 276.0 & 266.0 & 259.0 \\
\hline $\mathrm{TDN}^{5}\left(\mathrm{~g} \mathrm{~kg}^{-1}\right.$ of DM$)$ & 696.0 & 693.0 & 690.0 & 687.0 & 685.0 \\
\hline
\end{tabular}

${ }^{1}$ Neutral detergente fiber; ${ }^{2}$ Acid detergente fiber; ${ }^{3}$ Total carbohydrate, Sniffen et al. (1992); ${ }^{4}$ Non-fibrous carbohydrate, Sniffen et al. (1992); ${ }^{5}$ Total nutrients digestible, Weiss et al. (1998).

Animals were kept in metabolism cages fitted with two aluminum feeders, which supplied hay and concentrate separately, and a plastic bucket for water. Total fecal collection was carried out using collection bags for each animal from the $8^{\text {th }}$ to the $13^{\text {th }}$ day of each evaluation period.

The coast cross hay and citrus pulp were ground separately in electric grinding mills with $5 \mathrm{~mm}$ mesh size sieves in order to avoid ingredient selection by animals in the concentrate rations, and to minimize losses.

The animals were first subjected to a preexperimental period (10 days) to enable their adaptation to the metabolism cages, and concentrate and hay intake. In addition, they were dewormed and given a vitamin complex based on vitamins $\mathrm{A}$, $\mathrm{D}$, and $\mathrm{E}$.

Feed, orts, and feces collection was performed twice daily (07:00 $\mathrm{h}$ and 17:00 $\mathrm{h})$, from the $8^{\text {th }}$ to the $13^{\text {th }}$ day of each experimental period. Immediately after collection, samples were placed in plastic bags properly identified, weighed, and frozen at $-18{ }^{\circ} \mathrm{C}$. At the end of each experimental period, samples were unfrozen at room temperature. Afterwards, samples were oven-dried $\left(60 \pm 5^{\circ} \mathrm{C} ; 72 \mathrm{~h}\right)$, ground to $1 \mathrm{~mm}$ using a Willey mill, packed in plastic bags, and stored for further analysis.

Total feces collection was performed twice daily (07:00 h and 17:00 h) using collection bags. Immediately after collection, samples were placed in plastic bags properly identified, weighed, and frozen at $-18{ }^{\circ} \mathrm{C}$. At the end of each experimental period, fecal samples were unfrozen at room temperature for fecal composite sample elaboration. Fecal composite samples were elaborated by homogenizing all the samples obtained from the same animal during the same period, and sampling a portion of approximately $40 \%$. Immediately after this procedure, fecal samples were oven-dried 
$\left(60 \pm 5{ }^{\circ} \mathrm{C} ; 72 \mathrm{~h}\right)$. Samples were then ground to 1 $\mathrm{mm}$ through a Willey mill and stored for further analysis.

Samples of feed, orts, and feces were analyzed for the contents of dry matter (DM) at $105^{\circ} \mathrm{C}$, crude protein (CP), ether extract (EE) and ash (AOAC, 1990), neutral detergent fiber (NDF), acid detergent fiber (ADF), and lignin (LIG) were analyzed according to the methods described by Van Soest et al. (1991). Carbohydrate fractions were determined according to Sniffen et al. (1992). Nitrogenous fractions were analyzed following the protocol described by Licitra et al. (1996).

A direct method was used to determine the apparent digestibility of the nutrients by evaluating the levels of nutrients in feed samples and feces. The apparent digestibility (AD) was obtained using the equation described by Coelho da Silva and Leão (1979): $\mathrm{AD}=[(\mathrm{Nf}-\mathrm{No}-\mathrm{Nfc}) /(\mathrm{Nf}-\mathrm{No})]^{* 100}$, where $\mathrm{Nf}=$ nutrient in feed $(\mathrm{g}), \mathrm{No}=$ nutrient in orts (g), and Nfc = nutrient in feces (g).

The total digestible nutrients (TDN) contents of feedstuffs and diets were estimated according to the equation described by Weiss et al. (1998). Total TDN content of diets and its intake were calculated after the digestibility assay using the equation described by Sniffen et al. (1992): TDN (g/d) = $\mathrm{DCP}+2.25^{*} \mathrm{DEE}+\mathrm{TDCH}$, where $\mathrm{DCP}=$ digestible crude protein, $\mathrm{DEE}=$ digestible ether extract, and $\mathrm{TDCH}=$ total digestible carbohydrates.

The digestible energy (DE) and metabolizable energy (ME) intake were calculated according to NRC (2007), considering that $1 \mathrm{~kg}$ of $\mathrm{TDN}=4.4$
Mcal of DE and that approximately $82 \%$ of $\mathrm{DE}$ is metabolizable $(\mathrm{ME}=0.82 * \mathrm{DE})$.

The rumen fluid was collected on the last day ( $14^{\text {th }}$ day) of each experimental period $3 \mathrm{~h}$ after morning feeding (ZEOULA et al., 2003), by using an esophageal silicone probe connected to a vacuum pump. Approximately $50 \mathrm{~mL}$ of rumen fluid was collected from each animal. The $\mathrm{pH}$ was measured immediately after collection by using a digital potentiometer (Tecnal ${ }^{\circledR}$, TEC 3MP). Samples were filtered through three layers of cheesecloth, and two aliquots of $10 \mathrm{~mL}$ each were taken per sample. Aliquots were placed in pots containing eight drops of sulfuric acid $(50 \% \mathrm{v} / \mathrm{v})$ in order to determine ruminal ammonia $\left(\mathrm{NH}_{3}-\mathrm{N}\right)$ concentration. The $\mathrm{NH}_{3}-\mathrm{N}$ concentration in rumen fluid samples was determined by distillation with $2 \mathrm{~N} \mathrm{KOH}$ according to the methodology described by Preston (1995).

Data were subjected to normality test for distribution of errors (Shapiro-Wilk test) and, subsequently, to analysis of variance $(\alpha=0.05)$. Mean values were studied by regression analysis using t-tests $(\alpha=0.05)$.

\section{Results and Discussion}

The citrus pulp inclusion did not have any effect $(\mathrm{P}>0.05)$ on the intake of nutrients (Table 3). Dry matter intake (DMI) did not change if the maximum level of citrus pulp inclusion was below the inclusion limit established by Ammerman and Henry (1991), which is $30 \%$ of citrus pulp in the total DM (Table 2). 
Table 3. Nutrients intake by lambs in diets containing citrus pulp replacing corn meal.

\begin{tabular}{|c|c|c|c|c|c|c|c|c|}
\hline \multirow{2}{*}{ Nutrient } & & \multicolumn{5}{|c|}{ Replacement level (\% DM basis) } & \multirow{2}{*}{ Mean } & \multirow{2}{*}{$\mathrm{CV}^{1}(\%)$} \\
\hline & & 0 & 25 & 50 & 75 & 100 & & \\
\hline \multirow{3}{*}{ Dry matter } & $\left(\right.$ g day $\left.^{-1}\right)$ & 1143 & 1148 & 1136 & 1164 & 1133 & 1145 & 2.48 \\
\hline & $\left(\mathrm{g} \mathrm{kg}^{-1}\right.$ of $\left.\mathrm{BW}^{0,75}\right)$ & 91 & 90 & 90 & 92 & 84 & 89 & 8.77 \\
\hline & $\left(\mathrm{g} \mathrm{kg}^{-1}\right.$ of $\left.\mathrm{BW}\right)$ & 39 & 39 & 39 & 40 & 35 & 38 & 10.83 \\
\hline Organic matter & $\left(\mathrm{g}\right.$ day $\left.^{-1}\right)$ & 1079 & 1081 & 1069 & 1090 & 1061 & 1076 & 2.49 \\
\hline Crude protein & $\left(\right.$ g day $\left.^{-1}\right)$ & 150 & 152 & 149 & 153 & 152 & 151 & 2.90 \\
\hline Ether extract & $\left(\right.$ g day $\left.^{-1}\right)$ & 16 & 13 & 13 & 17 & 14 & 14 & 15.8 \\
\hline \multirow{2}{*}{$\mathrm{NDF}^{2}$} & $\left(\right.$ g day $\left.^{-1}\right)$ & 621 & 621 & 619 & 633 & 614 & 621 & 2.27 \\
\hline & $\left(\mathrm{g} \mathrm{kg}^{-1}\right.$ of $\left.\mathrm{BW}\right)$ & 21 & 21 & 21 & 22 & 19 & 21 & 10.27 \\
\hline $\mathrm{TC}^{3}$ & $\left(\mathrm{~g} \mathrm{day}^{-1}\right)$ & 914 & 917 & 907 & 921 & 896 & 911 & 2.44 \\
\hline $\mathrm{NFC}^{4}$ & $\left(\mathrm{~g} \mathrm{day}^{-1}\right)$ & 341 & 345 & 338 & 338 & 328 & 338 & 3.46 \\
\hline
\end{tabular}

${ }^{1}$ Coeficient of variation, ${ }^{2}$ Neutral detergente fiber, ${ }^{3}$ Total carbohydrate, ${ }^{4}$ non-fibrous carbohydrate

The DMI values $\left(\mathrm{g} \mathrm{day}^{-1}\right)$ were similar to those reported by Henrique et al. (2003); however, in contrast to our study, these authors observed an increase in DMI, probably due to a higher citrus pulp assimilation by animals, or due to citrus pulp composition variations resulting from processing. The DMI values observed in our study are in agreement with those predicted by NRC (2007), which estimated DMI values of $1190 \mathrm{~g} \mathrm{day}^{-1}$ of dry matter (DM) and 39,7 $\mathrm{g} \mathrm{kg}^{-1}$ of body weight (BW) for $30 \mathrm{~kg}$ animals. The crude protein intake in all experimental diets met the requirements predicted by NRC (2007) (140 $\left.\mathrm{g} \mathrm{day}^{-1}\right)$.

The mean intake values of DM, organic matter, ether extract, neutral detergent fiber (NDF), and total carbohydrate (TC) expressed as a function of metabolic weight are close to the results found in the literature (ALVES et al., 2003; MOREIRA et al., 2001; PEREIRA et al., 2008; VÉRAS et al., 2005). The intake control of nutrients is attributed to the physical effect of the rumen fill represented by high NDF intakes both in \% of BW and in $\mathrm{g} \mathrm{kg}^{-1}$ of $\mathrm{BW}^{0.75}$. However, a higher or lower NDF intake is mainly related to the NDF quality.

It is noteworthy that the nutrient intake was not influenced by citrus pulp inclusion as no effect $(\mathrm{P}>$ $0.05)$ in digestibility was observed when the same amount of corn was replaced by citrus pulp (Table 4) due to the higher proportion of roughage in the experimental diets.

Table 4. Apparent digestibility of nutrients $(\mathrm{g} / \mathrm{g})$ in diets for lambs containing citrus pulp replacing corn meal.

\begin{tabular}{lccccccc}
\hline \multirow{2}{*}{ Nutrient } & \multicolumn{9}{c}{ Replacement level (\% DM basis) } & \multirow{2}{*}{ Mean } & $\mathrm{CV}^{1}$ \\
\cline { 2 - 6 } & 0 & 25 & 50 & 75 & 100 & & $(\%)$ \\
\hline Dry matter & 0,639 & 0,651 & 0,658 & 0,639 & 0,658 & 0,649 & 2,9 \\
Organic matter & 0,650 & 0,66 & 0,669 & 0,648 & 0,666 & 0,659 & 2,8 \\
Crude protein & 0,702 & 0,717 & 0,725 & 0,718 & 0,731 & 0,719 & 2,5 \\
Ether extract & 0,453 & 0,452 & 0,444 & 0,459 & 0,434 & 0,448 & 6,0 \\
$\mathrm{NDF}^{2}$ & 0,527 & 0,544 & 0,554 & 0,530 & 0,554 & 0,542 & 5,4 \\
$\mathrm{TC}^{3}$ & 0,644 & 0,657 & 0,663 & 0,640 & 0,659 & 0,652 & 2,9 \\
$\mathrm{NFC}^{4}$ & 0,868 & 0,871 & 0,874 & 0,861 & 0,868 & 0,868 & 0,8 \\
\hline
\end{tabular}

${ }^{1}$ Coeficient of variation, ${ }^{2}$ Neutral detergente fiber, ${ }^{3}$ Total carbohydrate, ${ }^{4}$ non-fibrous carbohydrate 
The nutrient digestibility results reported in the literature (BUENO et al., 2002; FEGEROS et al., 1995; HENRIQUE et al., 2003; ÍTAVO et al., 2000; RODRIGUES et al., 2008b) show a wider variation than those observed in our study. This can be attributed to the fact that the citrus pulp composition varies depending on the type of fruit being processed and the processing method. Thus, there is not a standard for the marketing of this byproduct.

The TC digestibility values were close to those of DM, which was intuitive, since the consumption of neither was affected by the addition of citrus pulp to the diet (Table 3). The non-fibrous carbohydrate (NFC) digestibility was high (0.87), because this fraction is readily degraded in the rumen. The average value of NFC digestibility was close to that reported by Detmann et al. (2006) (0.90).

The content and intake of net energy for maintenance (NEm), and total digestible nutrients $(\mathrm{TDN})$ were not affected $(\mathrm{P}>0.05)$ by replacing corn with citrus pulp (Table 5). This is in accordance with the observation that the intake of other nutritional components was not influenced either. Similarly, França et al. (2012) and Zeoula et al. (2003) did not observe any effects on NEm when corn was replaced by bakery waste or cassava flour.

Table 5. Contents and intakes of total digestible nutrients (TDN) and net energy for maintenance (NEm).

\begin{tabular}{lccccccc}
\hline \multirow{2}{*}{\multicolumn{1}{c}{ Variable }} & \multicolumn{9}{c}{ Replacement level (\% DM basis $)$} & \multirow{2}{*}{ Mean } & \multirow{2}{*}{$\mathrm{CV}^{1}(\%)$} \\
\cline { 2 - 5 } & 0 & 25 & 50 & 75 & 100 & & \\
\hline $\mathrm{TDN}^{2}\left(\mathrm{~g} \mathrm{~kg}^{-1}\right.$ of DM $)$ & 620.9 & 630.9 & 636.0 & 615.2 & 630.1 & 626.6 & 2.85 \\
$\mathrm{NEm}^{3}\left(\mathrm{Mcal} \mathrm{g}^{-1}\right)$ & 1.52 & 1.50 & 1.50 & 1.50 & 1.49 & 1.50 & 0.63 \\
$\mathrm{TDNi}^{4}\left(\mathrm{~g} \mathrm{day}^{-1}\right)$ & 711 & 725 & 725 & 720 & 713 & 719.0 & 3.44 \\
$\mathrm{Nem}^{5} \mathrm{i}^{5}\left(\right.$ Mcal g$\left.^{-1}\right)$ & 18.68 & 18.53 & 18.29 & 18.76 & 18.13 & 18.48 & 2.75 \\
\hline
\end{tabular}

${ }^{1}$ Coeficient of variation. ${ }^{2} \mathrm{TDN}$ : Sniffen et al. $(1992) ;{ }^{3} \mathrm{NEm}=\mathrm{NRC}, 2007 ;{ }^{4} \mathrm{TDNi}$ : TDN intake; ${ }^{5} \mathrm{ELm}-\mathrm{i}=$ Net energy for maintenance intake.

The inclusion of citrus pulp did not affect ruminal parameters (Table 6). Citrus pulp is characterized by low starch and high pectin content as compared to corn, which could have increased ruminal $\mathrm{pH}$ values, given the fermentation pattern of pectin (acetic fermentation). However, the rumen fluid $\mathrm{pH}$ values observed may have also been influenced by the roughage:concentrate ratio used (60:40). The greater participation of roughage, a primary factor that stimulates rumination and hence, saliva production, might have resulted in greater saliva production, which acts as a buffer, controlling the $\mathrm{pH}$ changes in the rumen.

Table 6. Ruminal parameters of lambs fed diets containing citrus pulp replacing corn meal.

\begin{tabular}{lccccccc}
\hline \multirow{2}{*}{ Parameter } & \multicolumn{9}{c}{ Replacement level (\% DM basis) } & \multirow{2}{*}{ Mean } & \multirow{2}{*}{$\mathrm{CV}^{1}(\%)$} \\
\cline { 2 - 7 } & 0 & 25 & 50 & 75 & 100 & & \\
\hline $\mathrm{pH}$ & 6.56 & 6.61 & 6.67 & 6.64 & 6.52 & 6.60 & 2.30 \\
$\mathrm{~N}-\mathrm{NH}_{3}\left(\mathrm{mg} \mathrm{dL}^{-1}\right)$ & 26.38 & 25.25 & 30.90 & 30.14 & 30.90 & 28.71 & 15.99 \\
\hline
\end{tabular}

${ }^{1}$ Coeficient of variation. 
Average $\mathrm{pH}$ values were higher than those indicated by Mould et al. (1983), probably to avoid decrease in fiber digestion $(\mathrm{pH}>6.2)$. Although rumen fluid might have been contaminated with saliva, the collection method minimized this risk. Furthermore, according to Oliveira et al. (2005), $\mathrm{pH}$ values smaller than 7.0 indicate little saliva contamination.

The $\mathrm{NH}_{3}-\mathrm{N}$ concentrations were considered to be within the optimum range to obtain the maximum microbial fermentation in the rumen (15 to $29 \mathrm{mg}$ $\mathrm{dL}^{-1}$ ), without exercising a negative influence on microbial growth or fiber degradation (PRESTON, 1986). The maintenance of an appropriate $\mathrm{NH}_{3}-\mathrm{N}$ concentration in the rumen is necessary to promote the growth of fibrolytic bacteria, which improve fiber digestion, because these bacteria exclusively use $\mathrm{NH}_{3}-\mathrm{N}$ as their nitrogen source (RUSSELL et al., 1992).

\section{Conclusion}

Citrus pulp can replace total corn in concentrate for lambs or up to $26.5 \%$ in the total dry matter (dry basis) without affecting intake and digestibility of nutrients, and ruminal fermentation parameters.

\section{References}

ALVES, K. S.; CARVALHO, F. F. R.; VÉRAS, A. S. C.; ANDRADE, M. F.; COSTA, R. G.; BATISTA, A. M. V.; MEDEIROS, A. N.; MAIOR JÚNIOR, J. S.; ANDRADE, K. B. Níveis de energia em dietas para ovinos Santa Inês: desempenho. Revista Brasileira de Zootecnia, Viçosa, MG, v. 32, n. 6, p. 1937-1944, 2003.

AMMERMAN, C. B.; HENRY, P. R. Citrus and vegetable products for ruminant animals. In: ALTERNATIVE FEEDS FOR DAIRY AND BEEF CATTLE, 1991, St Louis. Proceedings... St Louis: [s.n.], 1991. p. 103-110.

ASSIS, J. A.; CAMPOS, J. M. S.; VALADARES FILHO, S. C.; QUEIROZ, A. C.; LANA, R. P.; EUCLYDES, R. F.; MENDES NETO, J.; MAGALHÃES, A. L. R.; MENDONÇA, S. S. Polpa cítrica em dietas de vacas em lactação. 1. Consumo de nutrientes, produção e composição do leite. Revista Brasileira de Zootecnia, Viçosa, MG, v. 33, n. 1, p. 242-250, 2004.
ASSOCIATION OF ANALYTICAL CHEMISTS AOAC. Official methods of animalys. $15^{\text {th }}$ ed. Virginia: Arlington, 1990. $1117 \mathrm{p}$.

BUENO, M. S.; FERRARI JUNIOR, E.; BIANCHINI, D.; LEINZ, F. F.; RODRIGUES, C. F. C. Effect of replacing corn with dehydrated citrus pulp in diets of growing kids. Small Ruminant Research, Amsterdam, v. 46, n. 2, p. 179-185, 2002.

COELHO DA SILVA, J. F.; LEÃO, M. I. Fundamentos de nutrição dos ruminantes. Piracicaba: Ed. Livroceres, 1979. $384 \mathrm{p}$.

DETMANN, E.; VALADARES FILHO, S. C.; HENRIQUES, L. T.; PINA, D. S.; PAULINO, M. F.; VALADARES, R. F. D.; CHIZZOTTI, M. L.; MAGALHÃES, K. A. Estimação da digestibilidade dos carboidratos não-fibrosos em bovinos utilizando-se o conceito de entidade nutricional em condições brasileiras. Revista Brasileira de Zootecnia, Viçosa, MG, v. 35, n. 4, p. 1479-1486, 2006.

FEGEROS, K.; ZERVAS, G.; STAMOULI, S.; APOSTOLAKI, E. Nutritive value of dried citrus pulp and its effect on milk yield and milk composition of lactating ewes. Journal of Dairy Science, Champaign, v. 78, n. 5, p. 1116-1121, 1995.

FRANÇA, A. B.; MORENZ, M. J. F.; LOPES, F. C. F.; MADEIRO, A. S.; MORENZ, D. A.; FARIA, B. M.; CABRAL, L. S.; FONSECA, C. E. M. Bakery waste in sheep diets: intake, digestibility, nitrogen balance and ruminal parameters. Revista Brasileira de Zootecnia, Viçosa, MG, v. 41, n. 1, p. 147-153, 2012.

FRANZOLIN, R.; FRANZOLIN, M. H. T.; GOMIDE, C. A.; SCHALCH, E.; SILVA, J. R. Efeitos de dietas com polpa cítrica em substituição ao milho em grãos no concentrado sobre a degradabilidade e a fauna ruminal em bubalinos. Revista Brasileira de Zootecnia, Viçosa, MG, v. 29, n. 6, p. 2109-2118, 2000.

HENRIQUE, W.; SAMPAIO, A. A. M. Polpa de citros na alimentação de ruminantes. Jaboticabal: Funep, 1998. $59 \mathrm{p}$.

HENRIQUE, W.; SAMPAIO, A. A. M.; LEME, P. M.; LANNA, D. P. D.; ALLEONI, G. F.; COUTINHO FILHO, J. L. V. Desempenho e características da carcaça de tourinhos Santa Gertrudes confinados, recebendo dietas com alto concentrado e níveis crescentes de polpa cítrica peletizada. Revista Brasileira de Zootecnia, Viçosa, MG, v. 33, n. 2, p. 463-470, 2004.

HENRIQUE, W.; SAMPAIO, A. A. M.; LEME, P. R.; ALLEONI, G. F.; LANNA, D. P. D.; MALHEIROS, E. B. Digestibilidade e balanço de nitrogênio em ovinos alimentados à base de dietas com elevado teor 
de concentrado e níveis crescentes de polpa cítrica peletizada. Revista Brasileira de Zootecnia, Viçosa, MG, v. 32, n. 6, p. 2007-2015, 2003.

ÍtAVO, L. C. V.; SANTOS, G. T.; JOBIM, C. C.; VOLTOLINI, T. V.; FARIA, K. P.; FERREIRA, C. C. B. Composição e Digestibilidade Aparente da Silagem de Bagaço de Laranja. Revista Brasileira de Zootecnia, Viçosa, MG, v. 29, n. 5, p. 1485-1490, 2000.

LEIVA, E.; HALL, M. B.; Van HORN, H. H. Performance of dairy cattle fed citrus pulp or corn products as source of neutral detergent-soluble carbohydrates. Journal of Dairy Science, Madison, v. 83, n. 12, p. 2866-2875, 2000.

LICITRA, G.; HERNANDEZ, T. M.; van SOEST, P. J. Standardization of procedures for nitrogen fractionation of ruminant feeds. Animal Feed Science and Technology, Amsterdam, v. 57, n. 4, p. 347-358, 1996.

MIRON, J.; YOSEF, E.; BEN-GHEDALIA, D. Composition and in vitro digestibility of monosaccharide constituents of selected byproducts feeds. Journal of Agricultural and Food Chemistry, Freising, v. 49, n. 5, p. 2322-2326, 2001.

MOREIRA, A. L.; PEREIRA, O. G.; GARCIA, R.; VALADARES FILHO, S. C.; CAMPOS, J. M. S.; MORAES, S. A.; ZERVOUDAKIS, J. T. Consumo e digestibilidade aparente dos nutrientes da silagem de milho e dos fenos de alfafa e de capim-coastcross, em ovinos. Revista Brasileira de Zootecnia, Viçosa, MG, v. 30, n. 3, p. 1099-1105, 2001.

MOULD, F. L.; ØRSKOV, E. R.; MANNS, O. Associative effects of mixed feeds. I. Effects of type and level of supplementation and the influence of the rumen $\mathrm{pH}$ on cellulolysis in vivo and dry matter digestion of various roughages. Animal Feed Science and Technology, Amsterdam, v. 10, n. 1, p. 15-30, 1983.

NATIONAL RESEARCH COUNCIL - NRC. Nutrient requirements of small ruminants: sheep, goats, cervids and new world camelids. Washington: National Academic, 2007. 362 p.

NOCEK, J. E.; TAMMINGA, S. Site of digestion of starch in the gastrointestinal tract of dairy cows and its effect on milk yield and composition. Journal of Dairy Science, Champaign, v. 74, n. 10, p. 3598-3629, 1991.

OLIVEIRA, M. V. M.; LANA, R. P.; FREITAS, A. W. P.; EIFERT, E. C.; PEREIRA, J. C.; VALADARES FILHO, S. C.; PÉREZ, R. O. Parâmetros ruminal, sanguíneo e urinário e digestibilidade de nutrientes em novilhas leiteiras recebendo diferentes níveis de monensina. Revista Brasileira de Zootecnia. Viçosa, MG, v. 34, n. 6, p. 2143-2154, 2005.
PEREIRA, M. S.; RIBEIRO, E. L. A.; MIZUBUTI, I. Y.; ROCHA, M. A.; KURAOKA, J. T.; NAKAGHI, E. Y. O. Consumo de nutrientes e desempenho de cordeiros em confinamento alimentados com dietas com polpa cítrica úmida prensada em substituição à silagem de milho. Revista Brasileira de Zootecnia, Viçosa, MG, v. 37, n. 1, p. 134-139, 2008.

PRESTON, T. R. Analytical methods for characterizing. In: PRESTON, T. R. Feed resourses for ruminants. Better utilization of crop residues and by products in animal feeding: research guidelines. A practical manual for research workers. Rome: FAO, 1986. cap. 6, p. 5280 .

Biological and chemical analytical methods. In. PRESTON, T. R. (Ed.). Tropical animal feeding: a manual for research workers. Rome: FAO, 1995. p. 191264.

RODRIGUES, G. H.; SUSIN, I.; PIRES, A. V.; MENDES, C. Q.; ARAUJO, R. C.; PACKER, I. U.; RIBEIRO, M. F.; GERAGE, L. V. Substituição do milho por polpa cítrica em rações com alta proporção de concentrado para cordeiros confinados. Ciência Rural, Santa Maria, v. 38, n. 3, p. 789-794, 2008b.

RODRIGUES, G. H.; SUSIN, I.; PIRES, A. V.; MENDES, C. Q.; URANO, F. S.; CASTILlO, J. C. Polpa cítrica em rações para cordeiros em confinamento: características da carcaça e qualidade da carne. Revista Brasileira de Zootecnia, Viçosa, MG, v. 37, n. 10, p. 1869-1875, 2008a.

RUSSEL, J. B.; O'CONNOR, J. D.; FOX, D. G.; VAN SOEST, P. J.; SNIFFEN, C. J. A net carbohydrate and protein system for evaluating cattle diets: I. Rumen fermentation. Journal of Animal Science, Champaign, v. 70, n. 11, p. 3551-3561, 1992.

SNIFFEN, C. J.; O’CONNOR, J. D.; Van SOEST, P. J.; FOX, D. G.; RUSSELL, J. B. A net carbohydrate and protein system for evaluating cattle diets: II. Carbohydrate and protein availability. Journal of Animal Science, Champaign, v. 70, n. 11, p. 3562-3577, 1992.

VAN SOEST, P. J. Nutritional ecology of the ruminant. Ithaca, New York: Cornell, 1994. 476 p.

VAN SOEST, P. J.; ROBERTSON, J. B.; LEWIS, B. A. Symposium: carbohydrate metodoloy, metabolism, and nutritional implications in dairy cattle. Methods for dietary fiber, neutral detergent fiber, and nonstarch polysaccharides in relation to animal nutrition. Journal of Dairy Science, Madison, v. 74, n. 10, p. 3583-3597, 1991. 
VÉRAS, R. M. L.; FERREIRA, M. A.; ARAÚJO, C. V.; VÉRAS, A. S. C.; CARVALHO, F. F. R.; SANTOS, G. R. A.; ALVES, K. S.; MAIOR JÚNIOR, R. J. S. Substituição do milho por farelo de palma forrageira em dietas de ovinos em crescimento. Desempenho. Revista Brasileira de Zootecnia, Viçosa, MG, v. 34, n. 1, p. 249256, 2005.

WEISS, W. P. Estimating the available energy content of feeds for dairy cattle. Journal of Dairy Science, Champaign, v. 81, n. 3, p. 830-839, 1998.
WING, J. M.; VAN HORN, H. H.; SKLARE, S. D.; HARRIS JUNIOR, B. Effects of citrus molasses, distillers solubles and molasses on rumen parameters and lactation. Journal of Dairy Science, Champaing, v. 71, n. 2, p. 414-420, 1988.

ZEOULA, L. M.; CALDAS, S. F.; GERON, L. J.; MAEDA, E. M.; PRADO, I. N.; DIAN, P. H. M.; JORGE, J. R. V.; MARQUES, J. A. Substituição do milho pela farinha de varredura de mandioca (manihot esculentacrantz) em rações de ovinos: consumo, digestibilidade, balanços de nitrogênio e energia e parâmetros ruminais. Revista Brasileira de Zootecnia, Viçosa, MG, v. 32, n. 2, p. 491-502, 2003. 